\title{
Why do they (still) sing stories? Singing narratives in Tanjung Bunga (eastern Flores, Lamaholot, Indonesia)
}

\author{
DANA RAPPOPORT
}

\begin{abstract}
In eastern Flores, on the Tanjung Bunga peninsula (among Western Lamaholot speakers), several times a year, ritual narratives (opak) are performed on a square dancing area, where all the clans of the same ceremonial land meet. Three types of narrative are sung, according to three kinds of rituals. The article explains the context, content and performance details of these stories, performed all night long. Why do the various clans continue to sing all these narrative? What values do these long poems have for people who sing them? Until now, studies on this subject have been remarkably few, and not even a partial transcription or translation of these narratives is available. This article offers a preliminary insight into these sung narratives, to show how vital they still are in eastern Flores.

KEYWORDS

Narrative; singing; ritual; eastern Indonesia; Lamaholot; Tanjung Bunga.
\end{abstract}

Why do societies need to sing narratives? To focus on this topic at the beginning of the twenty-first century might seem anachronistic in a period in which modernity has already impinged upon so many societies even in the most remote places. However, even today, at the eastern tip of the island of Flores, people still perform narrative through singing and dancing all night. ${ }^{1}$ Called lian naman, 'singing on the dancing place', these narrative dancing

1 My thanks go to everyone in Flores, Solor, Adonara and Lembata, and to the singers of Lewotala, Belogili, Waiklibang, Riang Puho, Lebao and Keka'. My deepest gratitude also goes especially to Philip Yampolsky for all his comments and revisions on previous versions of this paper.

DANA RAPPOPORT is currently a fellow ethnomusicologist at the Centre for Southeast Asian Studies in Paris (CASE, CNRS-EHESS). Her research deals with Austronesian music of the Indonesian archipelago, studied by way of formal musicology, anthropology of religion and social organization. She is the author of Songs from the thrice-blooded land; Ritual music of the Toraja (Sulawesi, Indonesia) (Paris: Epistèmes, Maison des Sciences de l'Homme, 2009). Since 2006, she has explored the music of Eastern Indonesia. Dana Rappoport may be contacted at: danarapp@cnrs.fr. 
sessions occur all over the Tanjung Bunga Peninsula. ${ }^{2}$ Long dancing sessions are common to the whole Lamaholot-speaking area, including Lembata, Adonara and the Solor Islands. These sessions also include a succession of songs and dances, but as yet we do not know if these songs and dance are always interconnected into one grand narrative. However, on the Tanjung Bunga Peninsula, all the dances and songs which take place successively in one night do constitute a single narrative, divided into dance sections. Of all the categories of local songs, this kind of singing seems the most highly valued, probably because its narrative content is linked to important matters. Few studies about the content of these songs have been undertaken. Various reasons have contributed to this paucity, among them the complexity of local languages and the small number of researchers in this area. Although some myths have been collected (Taum 1996; Nong 2009), no collection of versified narrative songs has yet been published. Likewise although some forms of music from this region have been recorded (Yampolsky 1995; Rappoport 2010b, 2013) and studied (Messner 1989), no transcription or translation has appeared.

In this article, I offer an initial description of data I have gathered firsthand in Tanjung Bunga in the course of five fieldwork periods between 2006 and 2012. The paper focuses on the various kinds of narrative which I have recorded, although I have only transcribed one of them in its totality so far. By examining the content and performative aspects (social, literary, musical) of these narratives, I shall attempt to give answers to the questions: What do they sing? Why do they sing stories? How do they sing them?

\section{TANJUNG Bunga, EASTERN Flores}

Tanjung Bunga is a small peninsula at the very eastern tip of Flores, one of the last places in the Lamaholot linguistic area where traditional music is still performed in context and not as a staged performance (Figure 1). Around twenty villages, located all along the coast of the peninsula have maintained their traditional political system, but new forms of power, including those of the local government and the Roman Catholic Church, have been superimposed onto it. The name "Lamaholot" was given to these people only recently. Its first appearance was in academic writings (Robert Barnes 1993: 154). Before 1945, they were called "Solor peoples". The inhabitants call themselves ata kiwan ("people from inside, insiders'), rarely "Lamaholot". ${ }^{3}$

2 In former times, they were also performed in villages behind the volcano Ilé Mandiri and to the west as far as Lewokluo' and Lamika, but they are no longer performed there today. Jaap Kunst (1942: 7) gives a short description of a performance right at the beginning of his book, a dance that he saw in 1931.

Part of the Austronesian language family, the Lamaholot linguistic group occupies several islands, a rather unusual situation in Indonesia. It stretches from the eastern tip of Flores to Adonara, Solor, Lembata and also the coastline of Pantar and Alor. Lamaholot is considered a dialect chain. Including Lembata, the number of speakers of Lamaholot could be estimated at around 220, 000 in 2007. The Lamaholot dialect chain is segmented into thirty-three dialects, divided into three groups: western (Flores), central (Solor and Adonara) and eastern (Lembata). 


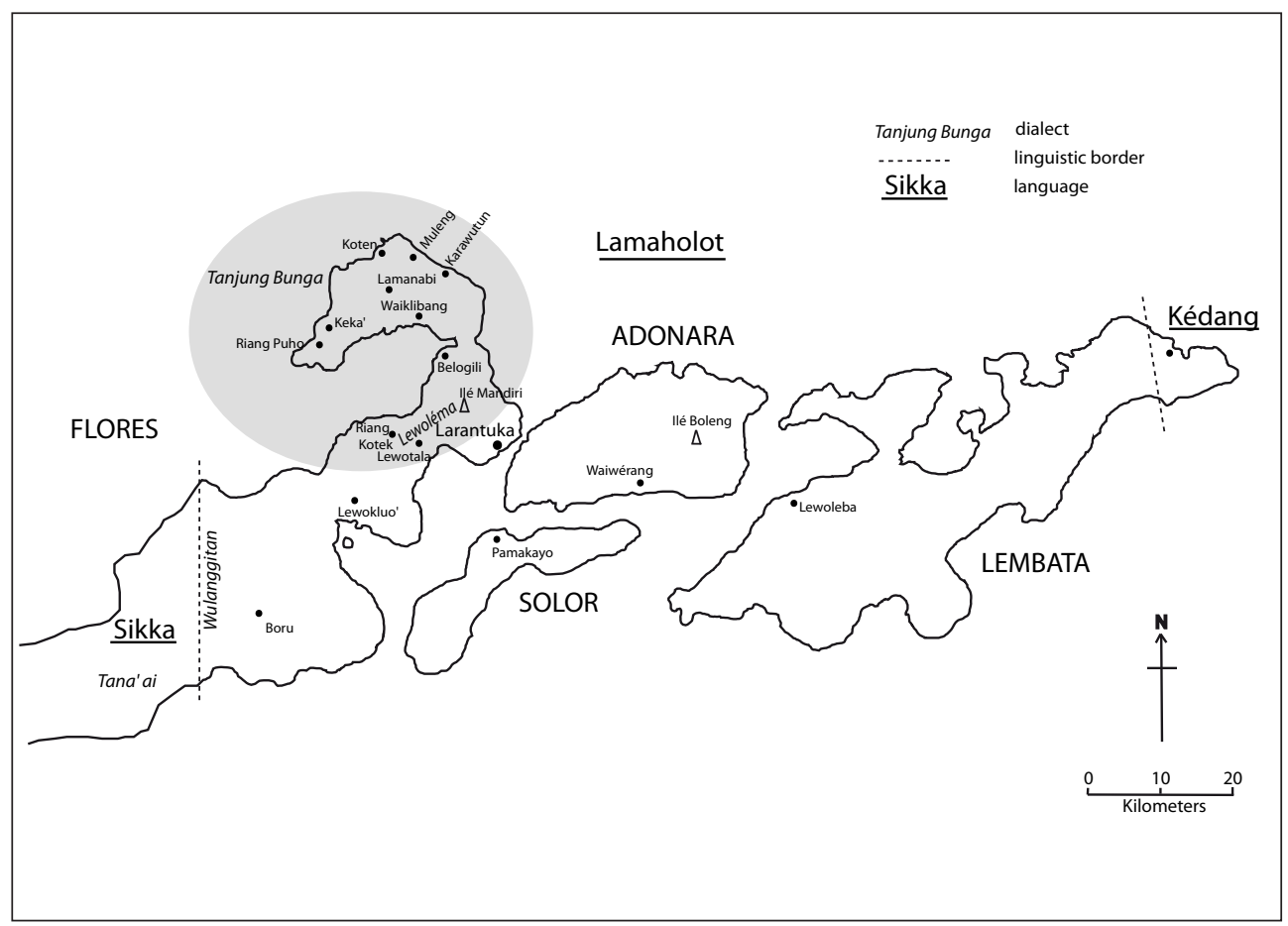

Figure 1. Map of the area.

In this eastern part of Flores, the Lamaholot-speaking populations live by the swidden cultivation of rice and maize on grubbed-up plots of land. Each village has from two to twelve clans (suku). In Tanjung Bunga, suku ('clan') refers to a group sharing a name, ancestors ( $k a k a$ bapa'), a place of origin, a ritual leader (madu mula), a ritual speaker (dé'i lau tonga raé, bokan maran), an "administrative" clan leader (Ind. bapa suku), a 'big house' (lango bélen'), a unilineal descent and specific prohibitions (wungun). Despite the fact Roman Catholicism reached Flores and the Solor Islands as early as the sixteenth century (Steenbrink 2003) and most Lamaholot-speakers claim to be Roman Catholics, a large proportion of the population still mixes its Catholicism with ancient customs, calling upon Lera Wulan - Tana Ekan ('Sun Moon - Land Field') and regularly feeding the land (huké tana) with animal offerings.

\section{NARRATIVE AS A LOCAL CATEGORY}

Despite extensive Christianization and the recent changes imposed by the government, Lamaholot societies have retained a strong link to their traditional spiritual life. The inhabitants still share their lands with non-human beings (nitun, harin, benakan'...) with whom they negotiate the exchange of various kinds of intangible goods at specific locations. Their relationships, never simple, consist of requests, exchanges and transactions, at certain locations

The western dialects are considered dominant (Keraf 1978: 8-10). Tanjung Bunga is considered one of the western dialects in the chain. 
throughout the land. Interaction with these non-human beings is conducted by a clan or a community of clans during rituals in which narratives (or stories) are sung in dance.

\section{EXPLORING THE VOCABULARY OF "NARRATIVE"}

Although the vocabulary varies from village to village, opak is the key Lamaholot word for "narrative", and it has a variety of meanings including: a sung narrative, to tell a narrative while singing and dancing and a "storyteller" ${ }^{4}$ It is important to emphasize the fact that narrative is invariably a musical performance, encapsulated in singing and dancing. The table below shows the stability of the term opak in the villages of the peninsula. This stability stands in stark contrast to varying terms for the other activities linked to the performance of these narratives (Figure 2). This table also makes absolutely clear that the storyteller is never alone; the performance of the narrative requires the participation of other singers.

\begin{tabular}{|c|c|c|c|c|}
\hline $\begin{array}{l}\text { Ceremonial } \\
\text { domain of }\end{array}$ & Waiklibang & Keka' & Lewotala & $\begin{array}{l}\text { Muleng, } \\
\text { Karawutun }\end{array}$ \\
\hline $\begin{array}{l}\text { to sing a } \\
\text { narrative } \\
\text { while dancing }\end{array}$ & opak (bélun) ${ }^{5}$ & $\begin{array}{l}\text { opak moran; } \\
\text { orun tion }\end{array}$ & $\begin{array}{l}\text { opak béle' } \\
\text { opak hodér ana'7 }\end{array}$ & opak \\
\hline $\begin{array}{l}\text { repertoire for } \\
\text { narrative }\end{array}$ & opak hodé' ana' & & opak hodé' ana' & \\
\hline storyteller & $\begin{array}{l}\text { opak } \\
\text { opak todo bawa } \\
\text { opak tuak } \\
\text { marak }\end{array}$ & $\begin{array}{l}\text { opak } \\
\text { opak todo bawa }\end{array}$ & opak & $\begin{array}{l}\text { opak } \\
\text { sason bawa } \\
\text { sason(g) rurén } \\
\text { bawa rogan }\end{array}$ \\
\hline $\begin{array}{l}\text { storyteller } \\
\text { embroiderer }\end{array}$ & $\begin{array}{l}\text { nukun kerun } \\
\text { nukun opak }\end{array}$ & noko opak & nukun kerun & nukun \\
\hline $\begin{array}{l}\text { dances } \\
\text { accompanying } \\
\text { the narrative }\end{array}$ & $\begin{array}{l}\text { haman } \\
\text { lian naman } \\
\text { nama nigi } \\
\text { nama néron }\end{array}$ & $\begin{array}{l}\text { haman } \\
\text { nama ligi }\end{array}$ & $\begin{array}{l}\text { hama } \\
\text { nama nigi }\end{array}$ & $\begin{array}{l}\text { haman mura } \\
\text { lian }\end{array}$ \\
\hline
\end{tabular}

4 In the Lewoléma dialect (Pampus 2001), the storyteller is called be'opak or opak alat.

5 Bélun is always paired with opak. It means berdendang (Pampus 2001) but could also be a variant of béle' 'grand'.

6 Moran 'to say'; tion 'to ask for'.

7 Literally 'to receive the child', but actually referring to the lines of the poem, because in a poem some lines are are called ina 'mother', other are called ana' 'child'. Poetry and music are based on the principle of complementarity ina ana' ('mother child').

8 'Short second voice'. 


\begin{tabular}{|l|l|l|l|l|}
\hline $\begin{array}{l}\text { soloist } \\
\text { performing } \\
\text { during the } \\
\text { narrative, } \\
\text { distinct from } \\
\text { the storyteller }\end{array}$ & $\begin{array}{l}\text { nukun belaha } \\
\text { nukun ana } \\
\text { nukut }\end{array}$ & & nukun & $\begin{array}{l}\text { nukun } \\
\text { ho'no }\end{array}$ \\
\hline $\begin{array}{l}\text { duets } \\
\text { within the } \\
\text { performance } \\
\text { of narrative }\end{array}$ & hodé' ana' & belo waen' & hodé' ana' & hodé' ana' \\
\hline
\end{tabular}

Figure 2. Table of vocabulary relating to sung narratives in four villages on the peninsula.

Importantly, the lexical field for "narrative" is distinct from the semantic field of ritual speech, which is in fact locally very rich. The latter is full of expressions, as the following table shows (Figure 3).

\begin{tabular}{|l|l|}
\hline koda & word \\
\hline koda tanawit & words linked to each other (Ind. kata sambung-menyambung) \\
\hline koda kenalan & ritual speech \\
\hline galan & to create metaphors, make allusions \\
\hline galan kenalan & $\begin{array}{l}\text { speech performed by two men in rapid alternation during a } \\
\text { ritual }\end{array}$ \\
\hline kirin, kehirin & to tell a story very rapidly at weddings or funerals \\
\hline koda kirin & to tell a story \\
\hline maran & $\begin{array}{l}\text { to pray before a sacrifice; name of the clan responsible for } \\
\text { this activity }\end{array}$ \\
\hline bokan maran & $\begin{array}{l}\text { ritual speech before an animal sacrifice, rapid, beginning by } \\
\text { a descending third. Syn. tutu marin }\end{array}$ \\
\hline tutu marin & 'to speak to say', to make a ritual speech. Syn. bokan maran \\
\hline tutu koda & to speak words \\
\hline tutut genatat & to lament at a funeral \\
\hline
\end{tabular}

Figure 3. Table of semantic field for various kinds of ritual speech, in Tanjung Bunga.

Many of the terms in Figure 3 are actually synonymous in sound (for example, galan kenalan and koda kirin are two kinds of rapid speech, but whereas the first is performed by two men, the latter is done by one only). Lamaholot sung narrative (opak) is distinct from other kinds of ritual speech because it is sung and because its delivery is long drawn-out and slow, whereas all other kinds of ritual speech are spoken in an unusually rapid manner (tutu marin, bokan maran, galan kenalan, koda kirin). ${ }^{9}$ 


\section{THE STORYTELLER (OPAK) IN HIS SOCIAL CONTEXT}

In Eastern Indonesian societies, whether it be sung or declaimed, ritual poetry is supposed to be efficacious. Besides being an aid to healing, it helps supplicate for rain, repulse the enemy and address the ancestors (Rappoport 2015). In Tanjung Bunga, the responsibility for ritual speech (prayers, sung poetry such as narratives and other songs) is entrusted to a single clan, the Maran, whose members are responsible for the words spoken before the animal offerings. ${ }^{10}$ In theory, four main clans (koten 'head', kélen 'tail', hurit 'slice,', maran ' pray') share the sacrificial responsibilities, each name indicating their obligations during the animal slaughter (one holds the animal's head, the other the tail, one cuts the head off and one prays). ${ }^{11}$ The one who prays is in charge of the ritual speech. In the village of Waiklibang, this sharing out of tasks was distributed fifteen generations ago, at the time of the principal ancestor Hajon Béra Puang Bala of the Lohayong dynasty. The task of singing stories is assigned to a clan whose ancestor allotted one of his sons the task of singing, talking and telling the story by 'standing to the sea watching towards the mountain' (de'i lau tonga raé). ${ }^{12}$ Hence the first Maran became a chanter (todo bawa) and healer (molan). Even today, the Maran clan is more expert than others in singing and speaking. Even though the dance is open to all, the majority of the dancers and singers do come (though not exclusively) from the Maran clan. This distribution of mastery in public speaking is also found in the neighbouring Sikkanese area (Tana 'Ai), where it involves the allocation of higher status to the clan responsible for recounting the history during the ritual ceremony Gren mahé (Lewis 1988: 98).

Several terms designate these persons in charge of speech (that we may call storytellers, chanters or master poets). Bawa or opak or todo bawa ('to beat the drum continuously') is the name of the storyteller, a title awarded to those who are able to sing long narrative sequences. A storyteller might also be referred to as sason rurén ('zither flute') or sason bawa ('zither drum'), phrases which link his art to musical instruments. All these designations indicate that this person is the one whose voice is heard. Bawa is also the designation of the first voice in a vocal duet (noko bawa); noko is the name of the second voice. Bawa is a reference to vocal and narrative mastery. ${ }^{13}$

10 The social structure consists of two kinds of clan: "sovereign/lord" status, suku raja tuan and the other, subordinate status, suku wu'un 'new clans'.

11 This quadri-partition does not appear as a model everywhere. In Waiklibang, instead of four sovereign clans, there are only three.

12 Lau : to the sea, where the sea spirits harin; raé, the mountain where the spirits of the land (nitun) reside. The meaning may be that he is in relation both with the harin and nitun spirits.

13 Todo means 'to hit, to help' and bawa has several meanings: 1 ) in the north of Tanjung Bunga, it is sometimes the name of the first voice in a two-part song; 2) to guide ; 3 ) in Lembata, bawa(r) means 'drum' (Kédang, Ilé Apé, Watuwaer). An interesting connection can be made with Javanese and Sanskrit, as Marc Benamou has studied so extensively. In Javanese gamelan, bawa refers to a male authoritative voice. It usually refers to the extended, unmetred, solo vocal introduction to a gamelan piece, usually by a male singer. One of the meanings of mbawani is to 'begin, to rule', and this can be linked to the Sanskrit 'existence, manner, condition' (Benamou 
As they have the capacity to memorize the genealogies and the routes of migration, these chanters are the guardians of custom. It is believed that they have an innate ability to recite the history of ceremonial domains regardless of having inherited it from the mouth of another and indeed without even having been born in the place of which they sing. The memory they demonstrate in singing and storytelling and their mastery of lexical complementarity is shared only by a very small number of people. (As a poetic linguistic element, lexical complementarity is a prerequisite of any kind of ritual speech, as I shall explain later in this paper). If more than two people in a village master this art, a conflict might erupt. At the time of my fieldwork, three storytellers were living in Waiklibang: Paulus Platin Maran, the oldest (Figure 4), around eighty years old; Anton Sika Maran (around seventy-five) and Arnoldus Kebojan Maran (fifty-three) - in that order of precedence. As long as the oldest one is still alive, his younger rivals cannot perform the narrative if the oldest is present. In every ceremonial domain, one to three persons only are able to sing stories. Without the presence of at least one, the myth and dance cannot be performed.

In contrast to individual artistic performances which position performers as artists, storytellers are not considered artists but as key persons in maintaining the moral order of the community. Their responsibilities put them in danger should a performative fault occur, because words can influence the fate of the community. Their mission-mastering and performing ritual poetic narrative, thereby facilitating the reproduction of life-can cause the performer's death. In eastern Flores, as in many places in the Austronesian world, these men possess religious power, expressed through ritual poetry. To sing the narrative is a cognitive skill which has a specific aim: to set out the path. However, should this path be wrong, danger might befall the community:

We, as storytellers, tell of long journeys, from Larantuka, Ende or Maumere. I remember I was still a child when they rebuilt the great temple. They were dancing. One of the storytellers was from Belogili. I moved to stand close to him. He was reciting. My father laughed: "Ah, is this the right way or not? Is he acquainted with the temple or not?" After he returned home, two weeks later, he was dead. He did not know the [right] road. [He knew] a wrong road. We must know the way back. If we do not know it, we become lost. For example, [although] this way is said to be a good road, but it is a fire road, a wrong road. I was still in the second class of primary school, around 1959. (Storyteller Paulus Platin Maran, p.c., Waiklibang, 2010). ${ }^{14}$

2010: 154, note 33). Benamou notes that a bawa singer needs to be berwibawa (to exude masculine authority) or needs to have wibawa (prepotency: greater than others in power or influence). Someone who is berwibawa has the power to control people, not by threats or force, nor by coquettish allure, but through his commanding presence. "Whenever someone sings a bawa, his wibawa usually affects all of his surroundings: everyone gets quiet and listens. He has to show that his is a male voice, he has to appear manly. That's how bawa are". (Benamou 2010: 154).

${ }_{14}$ Kami opak ciri jalan jalan jauh di Larantuka atau di Ende atau di Maumere. Mereka bangun koké besar dalam balé, saya masih kecil. Mereka haman. Salah satu dari Belogili. Saya datang berdiri dengan opak. Dia opak terus. Bapa' saya tertawa: "ah jalan baik atau tidak? Dia tahu balé atau tidak?" 
The risk of death as a consequence of the incorrect performance of narrative often recurred in the interviews I had with storytellers.

Many storytellers have already died [because of their accounts]. My mother told me: Bojan, don't go in for storytelling (opak), if you do, you will die. But I answered: "If I have to die, let me die. However, if I safeguard the customs of Waiklibang, Lewohajong, I shall not die." The rules for storytelling are so complex, so difficult. ${ }^{15}$ (Storyteller Arnoldus Kebojan Maran, p.c., Waiklibang, 2007).

These skilled performers not only master the art of story singing, they are also accomplished in other important fields of life. The storytellers, masters of allusion and metaphor (kenalan alat), ${ }^{16}$ can sometimes also be healers (molan). Their prowess might also extend to prediction, interpretation and various kinds of knowledge: historical knowledge, as they know the genealogies of all the clans of a ceremonial domain; literary knowledge, as they know the words of the poetry and the paired language (kenahan' kenape'); musical ability, as they are dexterous in performing the lines in the proper rhythm and with the right intensity.

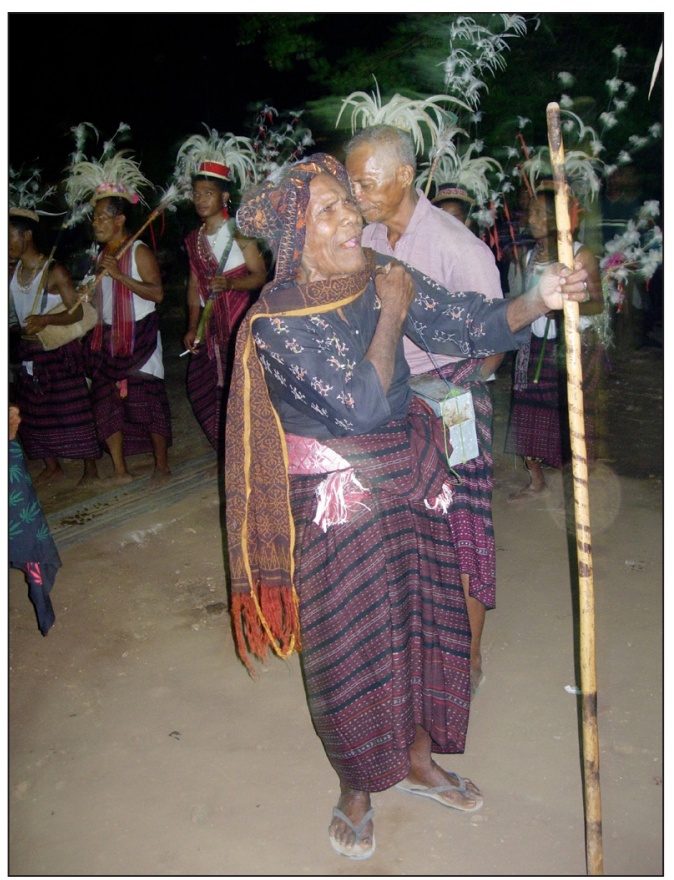

Figure 4. A storyteller, Bapa' Paulus Platin Maran, Waiklibang (photograph by the author, 2006).

Dia pulang, tidak sampai dua minggu, terus mati. Dia tidak tahu jalan. Salah jalan. Jalan kembali harus tahu. Kalau tidak tahu, kita sesat. Umpama jalan di sini, kita bilang jalan baik, tapi jalan api, jalan salah. Saya masih SD kelas II. Sekitar 1959.

15 Opak sudah pernah banyak sekali meninggal. (...) Jadi saya punya mama bilang: Bojan, jangan opak, nanti mati. Jadi saya bilang: "mati, matikah". Tapi kalau saya mempertahankan demi di bawah adat Waiklibang, Lewohajong saya tidak mati. Aturan opak setengah mati, susah sekali.

16 From galan 'to make metaphors, allusions'. 
Their ability is thought of as a kind of magical spirit (named sason lurén below) which accompanies the storyteller:

The sason lurén [lit. zither flute] is inherited from our ancestors who came before us [but] who are here now. This is [what] a sason lurén [is]. It appears magically. We cannot see his body. When it is permitted us, we may only hear his sound, but we cannot see the shape of his body, his face. It is a magical person, it is the sason lurén. Why is that person called the source of knowledge? Because he can recount everything which has happened in history. Why does he know it all? Because he travelled the road beforehand, the sason lurén brings up the rear. He who can tell the opak bélun stories, who can make the bokan maran speeches, the sason lurén has both gone before and the one who does this now, the source of knowledge I mentioned, he follows later, because the sason lurén has travelled the road earlier. He comes magically. He sits on top of our heads. Not everyone, only those who are suited to it. He chooses this head, that head - these are the right ones. Then he sits down on those heads, and those people are called the sason lurén.

In this hamlet, I am the sason lurén. My own father who has died was also a sason lurén. But Simon Hado is not sason lurén. He is studying because he has a capacity to learn rapidly. But the sason lurén comes up on us like a hat (kenobo'). The sason lurén is magical, cannot be seen. Why is he called magical? In my case, when he came to me, I knew it. If truth be told, I should only know about my own village. Therefore, why am I able to recount [the history] of that [other] village? Because the sason lurén has shown me. He came in the form of a hat, he used my head, so I can now recount all of this without any notes. I can tell it directly from memory, with no writing, because the sason lurén showed me the road. He is like a teacher with a student. I know the histories. How can I tell the history of Waiklibang? How do I know that [since I am not from Waiklibang]? From the sason lurén. Not everyone knows the history of every hamlet. At the very most, the source of knowledge [sason lurén] comes to two people. More than one, three, four, five. No! If everyone knew, then there would be fighting, people fighting each other within hamlets, suku against suku. Why? I speak. If it comes to speaking, I too can speak. If they all know, they will fight each other interminably. Therefore not everyone is permitted to know. He comes in magical form. In Waiklibang, it is Bapa' Platin and Bapa' Méo. Lego is just kukak kolon. (Storyteller Anton Siku Mukin, 68 years old, p.c., Karawutun, March 2006).

This long quotation describes how the narrative skill is represented as having been acquired through a magical visitation. As these storytellers say, other singers are called kukak kolon (from kukak 'black bird' and kolon 'bird; male'), a metaphor for good singers who have not fully mastered the narrative sequences but who have a good voice and are skilled in the lexical complementarity. This expression is related to a story in which a man wished to acquire the voice of the kukak bird. When visiting the forest, he grabbed the bird and pulled out the inside of its beak. Four days later, the man lost his voice. Then, on the fifth day, he began to sing the song hodé ana', very melodiously. At his death, people saw a bird emerge from his body. The skill of these singers - vocal and lexical, but excluding any narrative ability - is the fruit of learning and practice. 
In short, these differences in name reveal the hierarchy between storytellers and singers. They indicate how much the sung narrative is valued and how it affects how well a ritual is performed.

The importance of a storyteller in the village is measured by his degree of superiority in comparison to the healer (molan) and to other singers. It is believed that the storyteller can fly with the aid of magic.

\section{THREE KINDS OF NARRATIVES}

In this section I describe three kinds of narrative which are found in different ceremonial domains of Tanjung Bunga: ${ }^{17}$ the narrative of the origin of rice (opak moran laran Tono Wujo); the narrative of clan origins (opak usu asa, opak bai béda) and the narrative of sharp weapons. These narratives are performed in different contexts (for the land, for special houses, for birth, for war) and for various groups (sometimes for the community of clans, sometimes for one clan only).

\subsection{NARRATIVE OF TONO WUJO'S ROAD (OPAK MORAN LARAN TONO WUJO), THE ORIGIN OF RICE}

As in other parts of Eastern Indonesia where there are no irrigated fields because of the lack of water, most people depend on shifting cultivation; they supplement their staple crops of rice and maize with a variety of secondary crops and also hunt deer, pigs and monkeys. As the area is dependent on a short rainy season, crop failure and famine are frequent. Consequently food, which is so difficult to obtain, is of primary importance, since crop failure can mean death. Therefore, perhaps because a bad harvest can threaten the very existence of these populations, many rituals are concerned with the agricultural work which governs the lives of the farmers.

Rice cultivation is only found in the Lamaholot region in eastern Flores and not on the eastern islands of Adonara and Lembata where maize is the only crop. Therefore in the former, in the course of each agricultural year, rice is associated with a whole ceremonial cycle. Song has an important place in this cycle, as I have shown elsewhere (Rappoport 2011). The calendar begins with the opening of new fields before the rainy season, roughly in December (Ind. musim barat). Fields are prepared; trees are cut down and burned. During this work, people sing certain songs. After being burnt off, the ceremonial garden (Ind. kebun adat) is ritually "cooled". On the eve of this big day, during the ritual dokan gurun ('to wrap up and put up'), the seed is shut up inside the rice granary. On this occasion, the narrative of the origin of the rice maiden is performed in a dance. This narrative will be performed again at sowing, harvest and threshing. Consequently, it is performed four times a year in Waiklibang, at each of the four main steps in the cycle: planting, harvest, threshing and storing. The agricultural calendar is marked by a cycle of rituals

17 Each village belongs to a ceremonial domain called lewo tana, a generic term for a ritual community and its land, consisting of a village (lewo) and its land (tana). 
which will be performed by the main land-owning clans in a village. Every land-owning clan must perform the agricultural rituals in one of its fields every year. Each of these clans (suku tuan tana) has to choose a field which will, for one year, become the "ritual garden" (man witi 'garden goat' [in which a goat will be sacrificed for the community]) because the person whose garden is chosen must also provide the animals to be sacrificed. Most songs in the calendar are tied to the myth of the origin of rice.

In Waiklibang, this narrative is called 'narrative of the road of Tono Wujo' (opak moran laran Tono Wujo). ${ }^{18}$ It tells of the coming of a young girl (Tono Wujo) who was transformed into rice. It has the same name in both Waiklibang and the neighbouring village of Keka'. An alternative name in Keka' is 'remembering the path of Tono Wujo' (Tono Wujo hukut laran). ${ }^{19}$ The narrative tells how food plants originated from the body of a sacrificed human being. Long ago, people ate only beans. In order to survive, a young girl orders her seven brothers to buy swords. She asks them to prepare a field, to clear and burn it, and then to kill her and other animals in the middle of the field. Her youngest brother kills her, and after a short time her body is transformed into rice and other vegetables. After that, she spread from one village to another. This myth of origin of rice is found in various forms in island Southeast Asia.

I recorded the myth of the origin of rice in November 2006 and transcribed it in the local language. The total number of lines (octosyllabic and hexasyllabic) is 2,268. ${ }^{20}$ As I have published the summary from Nene' Suban, in his seventies (Waiklibang, 2007) elsewhere (Rappoport 2011), here I shall give the commentary on this story by the great storyteller of Waiklibang, Paulus Platin Maran, just before he was about to sing it for eight hours.

It is the narrative of the wrapping up of the food. Here we tell the story of rice. Tonight we are wrapping up. This woman, we shall wrap her up tonight. She will be reborn as rice. A human will be changed into rice in this pondok [small house]. She will not die. Cucumbers, millet, rice, all come from this woman. She is changed into rice. Her teeth are maize. She is Nogo Gunu. This woman is changed into rice. She does this by herself. This happened at Maumere, her duty stretches to Lewokluo', Keban at Lamanabi, and finally, to Waiklibang. Her body is rice. The rice is not a woman, initially it was a spirit from inside, an effigy from inside, a spectre, named Jawa. The narrative and the dance run in this fashion: once there was a man Kokatuli Sanganara, I'm his child, Raja Platin Lela Tuan Sabu Mekat Tewo Uran. Her mother was Gowin Bura, and Gowin Bura married into the Sogén clan, she married Pati Sogén Lagalio. Their children were Kasa Rua, Jawa Ama, Butu Rua, Marin Bajo, La Loku, La Lodé, La Timu and Bala Harut.

18 The rice maiden is called by many names. In the eastern part of Flores, she is called Tono Wujo (or Biné Ana', Nogo Ema, Nogo Gunu, Ema Hingi, Besi Paré), but to the west of Lewokluo', she is called Belo Bési, Buno Paré, or Bési Paré.

19 An analysis of this myth in its context - with a summary but without transcription of the narrative - has been given by Karl-Heinz Kohl (2009: 305-450) who did fieldwork in Belogili.

${ }_{20}$ The whole can be listened at (http://archives.crem-cnrs.fr/archives/items/ CNRSMH_I_2007_006_001_232/).See Rappoport 2013. 
She is Nogo Gunu, the one who was changed into rice. Tonight, I shall tell this story. ${ }^{21}$

(Storyteller Paulus Platin Maran, 8 November 2006).

This summary tells how a human body is transformed into an edible plant, vital to the renewal of society. In the process of the cultivation of a crop, death is connected to fecundity. The story begins with the ancestors of the rice maiden, and a long part of the narrative is devoted to her genealogy, a résumé of which is given in Figure 5.

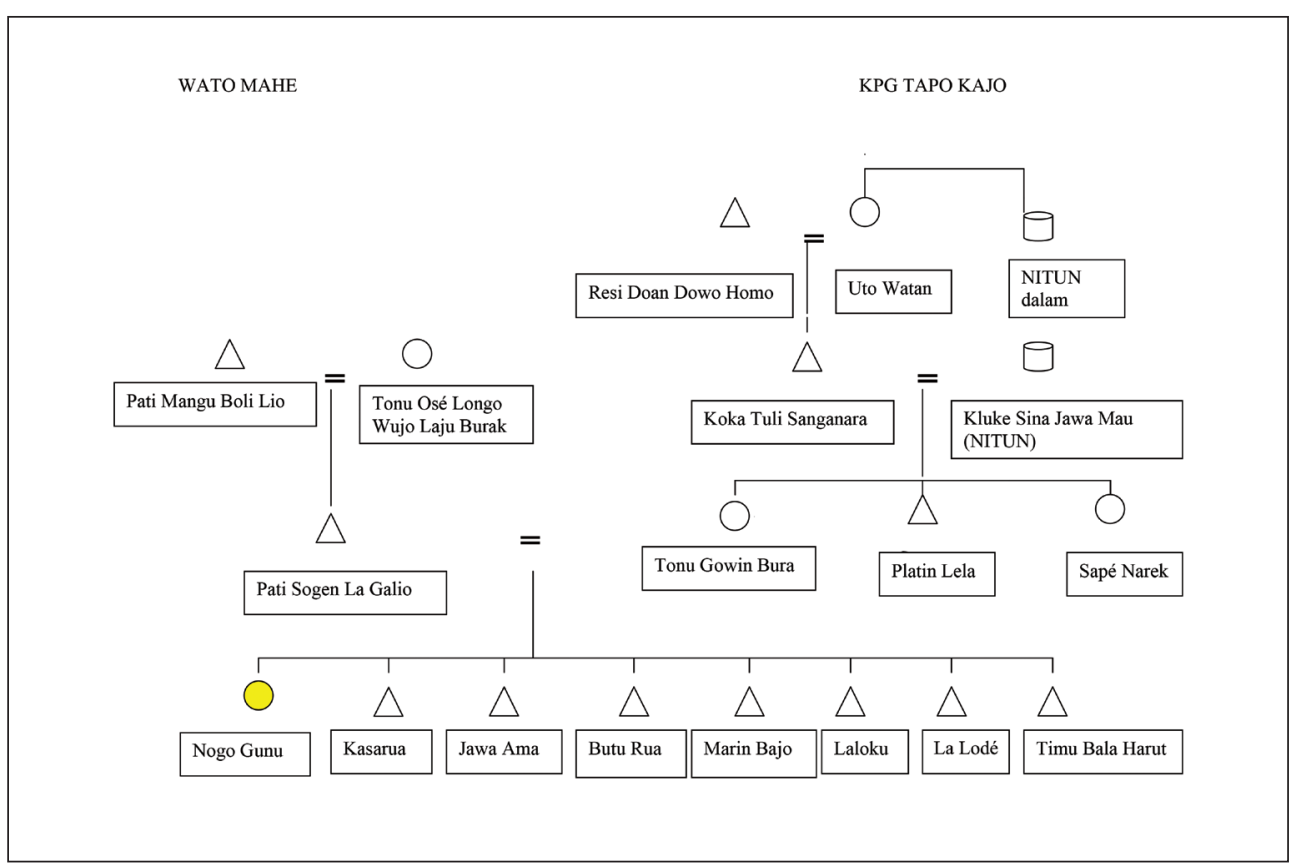

Figure 5. Genealogy of the rice maiden in the narrative.

One theme recurs in every version: the rice maiden is born of the union of a human with a nitun (terrestrial spirit) on her mother's side but, at the same time, the performers of the narrative link their own genealogy to that of the rice maiden. As a result, this myth of origin becomes a personal history in every village.

21 Opak gurun Be'ola. Ini cerita padi. Ini kita omong cerita padi. Ibu itu, kita gurun ini malam [masuk dalam granary], dia lahir padi itu. Manusia sendiri tukar padi di pondok. Bukan potong. Tidak mati, tidak meninggal. Ketimun, jarawawo, padi itu, semua itu dari perempuan tadi. Dia tukar padi. Giginya jagung. Itu Nogo Gunu. Ibu ini ditukar padi. Dia sendiri nona itu terbalik tukar padi. Itu di Maumere, tugasnya sampai di Lewokluo, di sini, Keban di Lamanabi, akhirnya di Waiklibang ini. Padi penghabis di Waiklibang. Ibu badan padi. Padi bukan ibu, yang pertama itu hantu dari dalam, patung dari dalam, pontianak, namanya Jawa, meria Jawa. Tapi opak itu begini, tandaknya begini: lakinya namanya Kokatuli Sanganara, itu lakinya, anaknya saya ini, Raja Platin Lela Tuan Sabu Mekat Tewo Uran. Biné satu namanya Gowin Bura, maka Gowin Bura itu ambil lakinya suku Sogén, namanya Pati Sogén Lagalio, maka anaknya Kasa Rua, Jawa ama, Butu Rua, Marin Baja, La loku, La Lode, La Timu, Bala Harut. Dengan anaknya namanya Nogo Gunu, maka dia terbalik tukar padi ini. Ini malam saya omong ini. 
The complexity of the overwhelming presence of names of characters, places and stones makes the narrative difficult to understand. For example, the grandfather of the rice maiden is called Raja Pati Mangu Tuan Boli Lio and her paternal grandmother is called Tonu Osé Longo Wujo Laju Burak (Figure 5). Apart from the genealogy, many other topics are also covered: places, spaces, various times, activities (burning the field, hunting, planting, eating), communication between humans and the world of spirits (nitun and harin), relations (kinship and alliance, the fraternal bond, maternal bond), the sacrifice, anxiety and emotion, the quest, the dowry and sexuality (for more details see Kohl 2009; Rappoport 2011, 2014).

Why do they need to tell this story four times a year? Societies in Eastern Indonesia did not grow rice until recently. In former times, they relied on the propagation of plants like taro (Colocasia esculenta), yams (Dioscorea) and banana. Coming from the west, the cultivation of rice might have modified their relationship to plants because "it is not the same thing to get fruits from a product or part of a plant that still lives, as it is to kill the plant in order to use it. To collect fruits from a tree, or collect palm sap does not destroy the plants (...). It is the contrary with annual plants like crops, in particular, rice, the harvest of which corresponds to its death" (Friedberg 2011:50). The killing (line 1,366 and the following), the loss and transformation at the very core of the narrative, produce a certain number of effects stimulated by singing. These patterns are encapsulated in the life of people and in their conception of human beings. When Lamaholot sing collectively about the rice maiden's transformation, they are genuinely sad to have lost a sister; they connect this mythical loss with real human losses (Rappoport 2013, 2014). This is made even more poignant for them, as every year a maiden is chosen to represent the girl supposed to be transformed into seed. During the entire cycle, her presence is represented by artefacts (an altar indicating the place where she will be "killed"; textiles and objects representing her comb and hair oil in the field). ${ }^{22}$ In a nutshell, this myth is not only expressed through singing and dancing, but also performed or represented.

In conclusion, why do Lamaholot still sing this story? A storyteller explained to me that this narrative is a way to welcome the rice maiden. In Lamaholot belief, the retelling of this story increases the fertility of the fields and the likelihood of a good harvest.

We want to welcome Tono Wujo to her village of origin. So we go there by flying, not by walking. Once there, we move hither and thither by walking, from Lio to eastern Flores, so the story which ends in the village begins with recounting her clans, her temple, her beach, we tell of her mountains, her spirits (nitun), her day, we tell everything, we must not make a mistake, that's why only one man knows it. If many of us know it, there will be war because nobody likes to be defeated. (Storyteller Anton Siku Mukin, 68 years old, p.c., Karawutun, March 2006).

22 Meran bélédan is the sacrificial altar on which the girl who performs as the rice maiden sits, before being "sacrificed" (Rappoport Forthcoming). 


\subsection{NARRATIVE OF ORIGINS (OPAK USU ASA), ROAD MIGRATIONS}

The narrative of (clan) origin is performed during the renewal of sacred buildings or for the birth of certain babies. In every village at least one temple (bale, koko, koké, korkê) and one 'big house' (lango bélen') can be found; moreover, in larger villages are various shrines (sebuan, podo) and a rice granary (kéban), each of these buildings is guarded by a different clan. Narratives are performed should a complete reconstruction of one of these buildings be required. On that occasion, people come to dance and sing the 'narrative of the origin' (opak usu asa) which recounts the road of the clans in their migrations as well as their genealogies.

What happens when temples and houses are rebuilt? Whereas most south-eastern local religions do not use temples or separate cult places (although there are some exceptions; see Waterson 1993: 48), this does not apply to many societies in Eastern Indonesia, where there is often a temple entirely dedicated to specific rituals or ceremonial purposes. From Flores to Alor, these ceremonial buildings are regularly renewed, although for various reasons they have disappeared here and there. In most of Tanjung Bunga, each ceremonial domain has a temple, in which an ensemble of local groups (clans) recognize themselves. ${ }^{23}$ The temple dedicated to the ancestors and the spirits is shared by all the clans of a ceremonial domain and is never the property of one clan only, although its guardian is the clan master of the land (Ind. Tuan tana). Although many of them were destroyed by the government in the 1970s, in some places they have been rebuilt (Robert Barnes 2011). Reserved for male dignitaries, the wooden temple is built on stilts and it is open on every side. The roof is usually thatched with vegetation (though sometimes the roof is made of corrugated iron). It is oriented towards the directions setting sun/rising sun (lali/héti) and sea/hill (lau/raé). Inside are stored a number of valuable objects (spears, bossed gongs, drums, fish bones, animal figures and sometimes anthropomorphic figures - Ratu 'male lord' and Nini 'female lord'). ${ }^{24}$ On top of the roof there is a wooden crocodile ( $k o b u$ $\left.w_{a j a}{ }^{\prime}\right)$, whose head faces the place of origin of the migration..$^{25}$ Every temple has different attributes. Through its symbolic power, linked to its regalia and to its ancestors, the temple concentrates a political and spiritual authority, reflecting the alliance of the clans who take this place as a point of reference, inferring that they belong to the same ceremonial domain.

23 This is true of the "Demon" parts of Tanjung Bunga. For centuries, a spatio-political dualism has determined the relationship between the Lamaholot villages. The space was divided between "Paji" and "Demon" lands. Each village belonged to one or the other of these divisions, rooted in a mythical conflict between two brothers who instigated rivalries lasting hundreds of years (Arndt 1938, 2002 ; Ruth Barnes 1987: 18; Robert Barnes 2005: 8).

24 The term probably refers to the Sanskrit in the thirteenth-century Old Javanese text, the Sumanasantaka, where nini-niny is the term of address for religious or female dignitaries (Acri 2014: 26).

25 This crocodile comes from a myth of origin in which humans emerge from a spirit transformed into a crocodile (Rappoport 2010a). 
In front of the huge temple at the centre is a dancing place, on which the nuba nara stones stand in a circle. ${ }^{26}$ All dances (nama nigi, nama neron, opak-hodé'ana', soka, hédung) which are performed around these stones turn anti-clockwise.

Every temple in each ceremonial domain is constantly being rebuilt, and all the clans are involved in its renewal. The great temple festival is called kerjan koko ('temple festival') or ahik koko ('temple renewal'). In former times, during the rebuilding of the temple, a human head was brought back from head-hunting to be planted under the main pillar (the pillar on the right-hand side), in order to reinvigorate its power, as if the people were feeding it with soul. In Tanjung Bunga, the head was hung from the same pillar to challenge the enemies to show their bravery in coming to retrieve it, keeping hostilities on the simmer. ${ }^{27}$ Today, pigs' heads have taken the place of human heads.

In 2006, the renewal of the temple in Lewotala village lasted two months (from September to 27 October 2006). ${ }^{28}$ The twelve clans of the village gathered. ${ }^{29}$ The old roof and the old pillars were destroyed and all the new materials gathered; the new wood was brought by villagers, singing as they came. Every two or three nights after the renewal process had begun, villagers came to dance in the dancing place in front of the building under construction. Saturday was the most animated night. Singers, their bodies decorated with feathers and various objects, sang from 10 p.m. until deep into the night (Figure 7). They sang fragments from the original story of a clan in chronological order. The narrative traced the story of the journey of the clans and the building of the temple. This story has a definite beginning and an end, the end being the day of the ceremony. The narration is therefore constructed to tell the original story of the clans and their travels and the story of the construction of the temple. The musical genre is called hodé ana' opak belé' ${ }^{30}$ The story had to be completed the day before the final celebration (ahik koké) - on the last day, only gongs and drums are allowed to be played.

Long narratives are also performed for other important buildings, such as clan houses (lango bélen', 'big house') which represent groups with a special status in the society. These groups are often called "land masters, land lords", "elders", "sovereign clans" (raja tuan). United by kinship and locality, they are linked to special houses which are celebrated in songs whenever they are

26 Sacred stones are distributed throughout the ceremonial domain and in all Lamaholot villages. These stones are distinct from other stones because they are considered the residence of spirits to whom humans address their requests. Humans come to dance in circle around them (Rappoport Forthcoming).

27 In 2011, an informant told me that humans took other humans "to reinforce large buildings and to imbue them with energy". Arndt $(1951: 79,2002)$ indicates that the renewal of customary houses required a human head to be planted under the principal pillar (rié wana, right pillar).

28 At Lewotala (eastern Flores), this renewal is called hone koke, or karjan koko, or ahik koko.

29 For a long time, they were eleven clans but now there are twelve: Hurit, Koton, Kelen, Tukan, Sogen, Hokor, Hewen, Hekin, Liwun, Wekin, Aran, Lepira.

30 Variant: haman hodé' ana' or hodé ana' nama nigi if the dance nama nigi is performed. 
rebuilt or renewed. Each "big house" is the place in which ancestral goods are stored. Although the other, less valued houses of the village clan (lango suku, 'house clan'), do have some regalia, but the "big house" is the mirror of a particular social group - the sovereign clan (raja tuan) - and through that, all the clans who have this house as a reference to their belonging to the ceremonial domain (lewo tana). Throughout the whole Lamaholot area, many rituals involving long narratives are performed for the celebration of big houses. This practice is found also elsewhere in Eastern Indonesia. The oral narrative of a clan's history legitimates its rights to land and concomitantly its ritual responsibility for this land. The ancestral origin of the sovereign clan is claimed through the chanted narrative. Consequently, the oral narrative puts the distinction and ritual seniority of one clan above the other, affirming its precedence and its right to social differentiation by retracing the founding of the domain.

\section{NARRATIVE OF THE BABY BOY (OPAK BAI BÉDA)}

The narrative of the baby boy is performed for one clan only, the Liwun clan, when a new baby boy is born. It is performed during the lodon ana' ritual ('the coming down of a child ') in the Lewoléma area (Lewotala, Kawaliwu, Riang Kotek, see Figure 1), in all villages in which Liwun clan members dwell, as well as in Waiklibang - where the ritual is supposed to have originated. The ritual must be performed for at least one child in a group of siblings. I witnessed it twice in 2006, at Riang Kotek and at Waiklibang. This ritual is also called bai béda ('baby boy'). It has been documented by Arndt (1940: 60), Graham (1991: 71-73) and Liwun (1986), but no transcription or analysis of the narrative has yet been offered.

At birth, the child and mother are kept secluded in one room in the house until the ritual has been carried out. The mother must cook for herself alone in her room. The child and the mother are not allowed to see daylight. Sometimes the child does not come out for months, and cases of rickets have been documented as a result. Usually the ritual should be held after forty days of seclusion but it actually only begins when the men of the Liwun clan have found eleven legs of deer or wild boar (babi hutan, rusa) (an uneven number is required, because uneven numbers are associated with life, whereas even numbers signify completion and death [Robert Barnes 1982: 17]). The legs of the deer or boar, stripped of their flesh, are hung in the child's room. The ritual begins in the afternoon. Male relatives on both the maternal (belakê) and paternal (opu) side bring presents and come to eat in the room of the child.

At night, dancers (from all clans) come to the front of the baby's house and begin to sing the history of the Liwun clan until dawn $(8$ a.m.). A storyteller comes to sing the narrative. Around 3 a.m., in the depths of the night, the child is awakened and a man pours water from a coconut on its head. The child cries and is ritually baptized. At dawn, after the story has been narrated the child is at last allowed to go outside with its mother. However, the child is not carried by the mother but by another woman of the Koten clan (Figure 6). A series 
of women come in line. They sit on a mat facing the mountain to present the child. The bones of the deer legs are cut up, mixed and cooked with papaya leaves. All eat this soup for the prosperity of the family.

Ben Liwun explained to me the story which was sung that night.

The origin of the Liwun clan is told. Initially there was a baby stranded on a rock in the sea. He was taken in by a woman from the Mukin clan to be raised in secret by marine spirits (harin). Then, at home, instead of milk, he was given salt water. He drank but did not grow. A bird, an eagle, landed on the roof of the house and indicated that the child had to be locked in the house. The narrative recounts the events from Keroko Puken Island [land of origin] to Waiklibang, where the child was released from his confinement. Before then, he was hidden in the house.

Eleven legs of animals must be found. It must be eleven, because it is a first child. Only seven or nine are requested for any later children. This must be odd, that is the way it is. If the ritual is not followed, the child might die. I know the story of a cousin who once at the end of the ritual, in the morning, replaced the deer or pig's legs with chicken on rice. Shortly afterwards, the child died. (Ben Liwun, p.c., Waiklibang, 8 November 2006.)

This ritual can be understood as the child's initiation into membership of the clan and into human society in general (Liwun 1986).

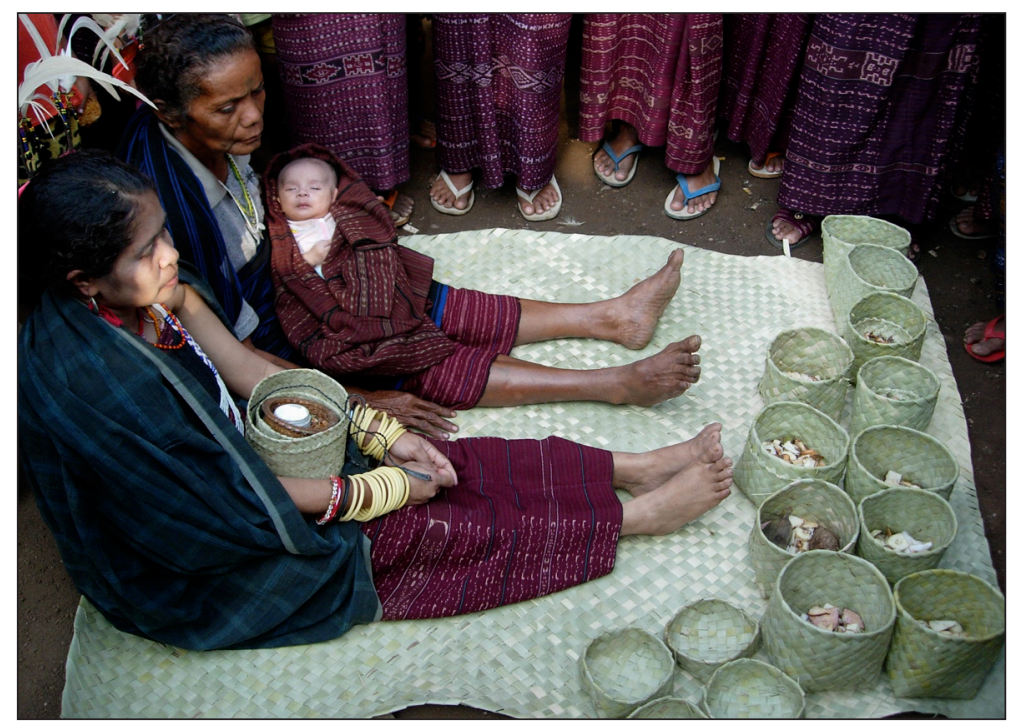

Figure 6. The baby during the lodon ana' ritual, Waiklibang, Kabupaten Flores Timur, Flores, 13 October 2006 (photograph by the author). 


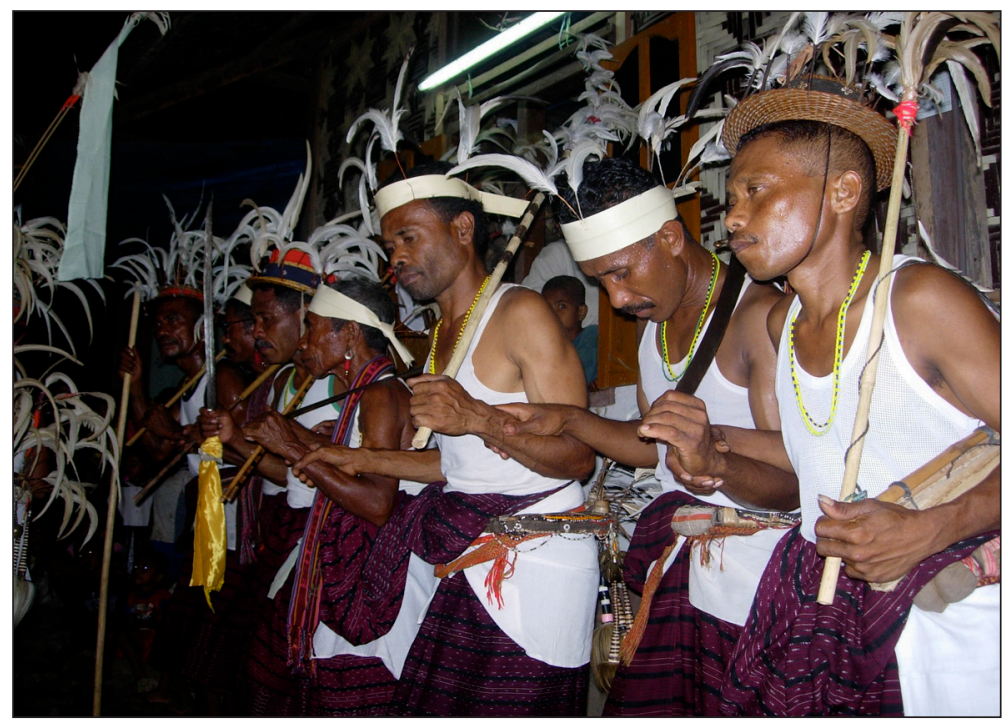

Figure 7. Dancers with swords during a ritual lodon ana' ('bringing down the child'), Riang Kotek, Kabupaten Flores Timur, Flores, 6 November 2006 (photograph by the author).

\subsection{NARRATIVE OF THE SHARP WEAPONS (OPAK SURI' KADA)}

The final kind of narrative to be discussed here is performed to invoke victory. Nowadays, it seems to be performed less than the two other kinds. Narratives are performed at different times at war shrines (sebuan, podo). Not all the villages have war shrines, but if they do not, they will have special stones close to the temple to visit before going to war. Unlike the [ritual] houses but like the temples, shrines are roofed but have no walls. At Lewotala, there are two war shrines, one kept by the Lango Aran clan, the other by the Hurit. These shrines are known as "hot" places. People visit them to solve collective burning issues arising from sporting competitions or a conflict.

At Belogili, on 27 September 2006, the Tenawahang clan decided to rebuild its war shrine, which was guarded day and night. I followed the process of its demolition and reconstruction. On this occasion, a narrative was sung (with dance) for two nights. Like their ancestors who were warriors, the Lamaholot have a long history of conflict between ceremonial domains. On the eve of a foray, a war party (but more frequently today on the eve of a football match), a group of men goes to the war altar, or to some ceremonial stones, two places at which humans communicate with spirits. These altars specially dedicated to conflict are used to supplicate for victory. At Waiklibang the altar which is called sebuan and guarded by the Sogén clan, was used before going to war against the neighbouring village of Lamaojang.

At night, the song of 'the sharp weapons' (opak suri' kada) invokes the power of these weapons during the dance, hoping that they will serve as warriors in the vanguard in battle. 
We observe the custom. What we are seeking by supplicating the ancestors is to be endowed with their powers (guna-guna). We come to feed the stones and we declare 'we want to go to war' (Ind. turun perang). All the men dance mura lian until dawn the next day and then leave for war. The chanter (opak) calls on all the powers, those of the sharp weapons. We ask that the powers go forth. We beseech all this. We draw our strength from all which is forbidden (Ind. ambil haram-haram membantu). We recount this narrative at the sebuan altar of either the Sogén or Lamaojang clan. Therefore we ask permission in advance for all which is prohibited (Ind. jadi barang yang haram, kami minta supaya lebih dulu). When we have decided to leave the next day, we dance that day. All weapons, they are put shut away and we dance until dawn. There is also spicy ginger (Ind. halia), we put it there, then all eat it. Those who do not feel its bite remain there. If you feel the heat, you go; if you do not feel the heat, you remain behind [otherwise] you will die. There are other large villages like us, if we did not have this power, we would not be as [great] as this. (Storyteller Arnoldus Kebojan Maran, p.c., Waiklibang, 10 June 2010).

In the Eastern Indonesian islands, music and dance supply the energy to fight, bestowing the strength to go to war and to celebrate victory when the warriors return. The connection between singing with war and head-hunting is clearly visible in the accoutrements of the dancers, who are equipped with swords and decked out with a host of other warlike accessories. Nowadays, although head-hunting has disappeared, combat dance rituals, accompanied by musical ensembles combining gongs, drums and voices, persist in new contexts. There are called hédung in Lamaholot. ${ }^{31}$

\section{FORMAL ASPECTS OF THE NARRATIVES}

So far, it seems that no study on Lamaholot poetic narrative has been carried out. My own data are based on the analysis of parts of one full narrative which I recorded and transcribed. I would like now to underline two aspects of the narrative: the performance aspects (how the music and the dance are combined with the narration) and the literary aspects (the principles on which the narration is built). These preliminary comments do not pretend to be exhaustive.

\subsection{MUSICAL AND DANCING ASPECTS}

\section{CYCLE OF VOICES}

The narratives haman opak bélun can consist of approximately 2,000 lines, probably more. Each narrative is built on a complex organization of musical voices. To the accompaniment of an isochronous pulsation, whose beat is stamped out by feet, three groups sing in alternation: the first is composed of the storyteller and his "embroiderer". ${ }^{32}$ The chant is then taken up by two

31 Sound example of the hédung dance: http:/ / archives.crem-cnrs.fr/archives/items/ CNRSMH_I_2007_006_001_357/.

32 The embroiderer is called nukun opak. As he is a very good singer, he adds a layer of vocal flourishes to the storyteller's voice by various techniques, most often overlapping and counterpoint. 
pairs of singers. The third participant is a soloist or secondary chanter. In all there is a minimum of seven singers: the narrator and his embroiderer (be'opak and nukun be'opak), two pairs of singers (hodé ana') and the secondary chanter (nukun belaha). ${ }^{33}$

The main chanter (opak), who has been consecrated by the community, recites the narrative for more than eight hours, at night. He is initially introduced by his embroiderer, who commences with a single melodic cell. As the embroiderer (nukun opak) repeats his last words, the narrator enters adding a layer of vocal flourishes. Every hundred lines, the storyteller (who sings in a syllabic recto tono declamation) is interrupted by a musical sequence involving two duets, four singers in pairs who 'take up the line' (hodé' ana'), the last line of the storyteller. This musical sequence contrasts with the preceding account of the myth: in it the dancers shout enthusiastically, breathing energy into the dance. Within a pair, each singer, responsible for a different voice (hodét or nukun, 'first or second voice'), faces the other. The second pair of singers repeats what the first pair has just sung. The musicality of their melodic phrases contrasts with the monotony of the storyteller's melody. The words of duets, often created by the singers themselves, are unimportant to the narrative. "Hodé ana', it is only a variation, a development; the opak and nukun chant the absolute essence, the essence of the ancestors is told", a singer informed me. The two pairs of singers are present to make intervals in the narrative.

\begin{tabular}{|c|c|c|c|}
\hline 1. Storytelling (Opak) & $\begin{array}{l}\text { 2. Two duc } \\
\text { (Hodé' ana' 't }\end{array}$ & $\begin{array}{l}\text { in response } \\
\text { eceive the line') }\end{array}$ & $\begin{array}{l}\text { 3. Free } \\
\text { improvisation }\end{array}$ \\
\hline $\begin{array}{c}2 \text { voices } \\
\text { 1. opak 'storyteller' }\end{array}$ & $\begin{array}{c}\text { Duet } 1 \text { (Ana' puken) } \\
\text { 'line origin' }\end{array}$ & $\begin{array}{c}\text { Duet } 2 \text { (Ana' wutun) } \\
\text { 'closing line' }\end{array}$ & 1 voice \\
\hline & $\begin{array}{l}\quad 2 \text { voices: } \\
\text { 1. hodé' } \\
\text { 2. nukun }\end{array}$ & $\begin{array}{l}\text { 2 voices: } \\
\text { 1. hodé' } \\
\text { 2. nukun }\end{array}$ & \\
\hline narrative & Duets, free vers & echoing the myth & $\begin{array}{l}\text { Improvisation } \\
\text { (optional) }\end{array}$ \\
\hline
\end{tabular}

Figure 8. Cycle of voices in the song narrative haman opak bélun.

Following the two duets (hodé' $a n a^{\prime}$ ), it might be the turn of a soloist (called nukun belaha 'long second voice' or nukun ana' 'second voice line') - long because this part is often lengthier than the utterance of the main storyteller. Semi-improvised, this secondary account might be related to the actual situation in the village, or it might depend on the singer's own mood. Although less important than the myth, this part can evoke a deep emotional response.

33 A recorded example of this kind of song can be found in Rappoport 2010b, Track 10, under the name mura lian. See also Rappoport 2011. 
As soon as the soloist (nukun belaha) finishes, the storyteller embroiderer (nukun be'opak) re-introduces the voice of the storyteller (opak). And the narrative cycle begins again (Figure 8).

What is the explanation of this succession of performers? The organization of the song is based on a well-marked assignment of musical tasks to specific performers:

Opak stops first, then comes the hodé ana'. They stop because people who are listening grow bored, because in this dance, opak is paired with hodé' ana', alternating with nukun belaha, so as to feel that the night can last a little bit longer. (Bapa' Arnoldus Kebojan Maran, Storyteller, p.c., January 2007).

Some remarks about the organization of voices should be added at this point. Most importantly musical knowledge is not shared by all. Singing requires an extreme mastery of storytelling and/or vocal technique. The polyphony always consists of two voices - overlapping between narrator and embroiderer, the polyphonic techniques of the hodé ana' duets. The ubiquity of duets in a collective dance raises the question why cannot the dancers invest more in the song to add more sound intensity to the whole. Except in the opening and ending sessions (called goken), at the very beginning and very end of the narration, the dancers do not participate in the singing during the chanting of the narrative. As an introduction and conclusion, the dancers meet the soloists with a vibrating "i ho!". Throughout the dance, their contribution is rhythmic; their ankle-bells mark the beat.

Musical form sheds light on the importance of the principle of age ranking (for the right to tell stories) and on the exclusivity of cycles, alternation of roles and hierarchy. The strict organization of the song is analogous to the strict organization of clans, ranked between seniors and cadets, land-masters and others, alternating the sacrificial tasks for the sake of collective efficiency.

\section{CYCLE OF DANCES}

The narratives are both sung and danced from the previous night until the next morning. The name of the dance varies even within the same village. Lian naman, 'song in the place of dance', or haman opak bélun, 'to thresh while telling the story', are the names most generally used.

Unlike all the other main round or chain dances of the neighbouring areas, which are performed holding hands or linking arms, for example, the dolodolo, lilin, and lian naman on Adonara, the haman opak bélun is performed in a line but not in a chain, as the dancers do not link hands or arms. The dancers stand in a semi-circle within which the singers remain and turn around the ceremonial stones. Four dancers - those who take their place at the front (gagi waé) - dance apart from the semi-circle; their function is to keep the dance alive. From time to time, they move their hips backwards and forwards by flexing their pelvises. Another dancer holding a spear who remains alone, also dances apart between the pairs of singers. All move according to a sequence of six steps, repeated throughout the whole night: left, right, left, right, right, 
left. The pulse is beaten out on the ground, marked by ankle-bells. On the last beat, there is no stamping; instead a virtual silence prevails. What is important in the dance is the motion of the pelvis, visually and sonically emphasized by the belt (kedewak), bells and chains, and goatskin and shell decorations, all of which reinforce the energy conveyed.

The narrative is organized according to a suite of repertoires, most of which are danced. Each repertoire is distinct by virtue of its name, variety of steps, melodic-rhythmic structures and configurations (line, circle, semi-circle, separate bodies ...). All these repertoires (Figure 9) are danced in a disjointed centripetal line. Below is an example of a musical suite called lian naman ('singing on the place of dance') performed for the narrative of the origin of the rice Waiklibang: ${ }^{34}$

\begin{tabular}{|c|c|c|c|}
\hline Hour & $\begin{array}{l}\text { Name of the } \\
\text { repertoire (dance } \\
\text { and song) }\end{array}$ & Sex & Description \\
\hline 23.30 & Haman opak bélun & M & $\begin{array}{l}\text { Line stamping turning anti-clockwise with } \\
\text { an invariable six-beat step L R L R R L. } \\
\text { Alternating duets and solos. }\end{array}$ \\
\hline 2.10 & Nama nigi & $\begin{array}{l}\mathrm{F} / \\
\mathrm{M}\end{array}$ & $\begin{array}{l}\text { Line turning anti-clockwise. Those who do not } \\
\text { sing mark the rhythm with sticks and bells. } \\
\text { Alternating duets and solos, } 16 \text { beat cycle. }\end{array}$ \\
\hline 3 & Lian kenolon & $\mathrm{F}$ & $\begin{array}{l}\text { Line dance, responsorial ; } 1 \text { duet }+1 \text { unison } \\
\text { female chorus with shouting. }\end{array}$ \\
\hline 4 & Haman Opak bélun & M & $\begin{array}{l}\text { Line stamping turning anti-clockwise with } \\
\text { an invariable six-beat step L R L R R L. } \\
\text { Alternating duets and solos. }\end{array}$ \\
\hline 4.45 & Nama néron & $\mathrm{F}$ & $\begin{array}{l}\text { Female line dance. } 1 \text { duet }+1 \text { unison female } \\
\text { chorus with shouting. At the end, women, } \\
\text { representing the seeds, are wrapped in } \\
\text { ancestral textiles (towe) and enter the rice } \\
\text { granary. }\end{array}$ \\
\hline 5.30 & Berasi & $\mathrm{F}$ & Singing seated duet. \\
\hline 6 & Soka & $\mathrm{F}$ & $\begin{array}{l}\text { Female collective dance to the sound of gongs } \\
\text { and drums. }\end{array}$ \\
\hline $6.15 \mathrm{am}$ & Hédung & M & Male war-dance with swords and daggers. \\
\hline
\end{tabular}

Figure 9. Example of a musical suite performed for the dokan gurun ritual - storage of the seed (Waiklibang, Flores Timur, 8 November 2006).

All the repertoires in this suite (Figure 9) are connected by a narrative continuity provided by multiple reciters, assisted by embroiderers. Despite the variety of dances which succeed one another throughout the night, the 
continuity of the narrative unites them all. Is the narrative shaped in a suite of dances and music a feature of many other Eastern Indonesia societies?

\subsection{LITERARY ASPECTS}

Turning to the literary aspects, I would like to emphasize two processes always used in these narratives: the sequencing of names and the pairing of words.

\section{SEQUENCING THE NAMES}

All the narratives - for rice, for clans, for war - recall journeys and ancestors (of the rice maiden, of ancestors, of spirits). The memory of the routes is fixed by the recitation of sequences related to migration, referring to place names enumerated in a fixed order. In the example below, at the beginning of the narrative of the origin of rice, the place of the paternal grandfather of the rice maiden is recalled in the name of the ceremonial domain, ancestors, ceremonial stones, spirits, mountains and lands. The chanter sings:

$\begin{array}{ll}\begin{array}{ll}\text { Lewo Wato Mahé } \\ \text { tana Belan Burak }\end{array} & \begin{array}{l}\text { Village Wato Mahé } \\ \text { land Belan Burak [lewo tana: ceremonial domain] }\end{array} \\ \begin{array}{ll}\text { Raja Pati Mangu } \\ \text { Tuan Boli Lio }\end{array} & \begin{array}{l}\text { Great Pati Mangu } \\ \text { Sovereign Boli Lio }\end{array} \\ \begin{array}{l}\text { Tonu Osé Longo } \\ \text { Wujo Laju Burak }\end{array} & \begin{array}{l}\text { Tonu Osé Longo } \\ \text { Wujo Laju Burak [full name of the rice maiden] }\end{array}\end{array}$

Nuba Sogé Sara Boro The nuba stone Sogé Sara Boro

béla Kéwa Kalamidi the béla stone Kewa Kalamidi [nuba béla: ceremonial stones]

Guna Siga Buga

déwa Tuli Nara

Ilé Wato Tena

woka Wai' Wuri

Duli Kebo Lolon Buto

pali Hulu Hala Lolon
Helping spirit Siga Buga

helping spirit Tuli Nara [guna déwa: helping spirit]

Mount Wato Tena (Stone boat)

hill Wai Wuri (Water Wuri)

Field named Kebo Lolon Buto

field named Hulu Hala Lolon [duli pali: ceremonial field]

Excerpt from the narrative opak bélun gurun gawak béola tugu, lines 143-156 (recorded at Ratulodong, dokan gurun ritual, 8 November 2006). 
The principal function of this topography or topogeny could be to establish the precedence of a group in the territory and its secondary function might be to store knowledge about the relationships and interconnections between past events and the secret names of spirits and places travelled through in the course of migrations. James Fox uses the term topogeny to refer to an ordered succession of place names, showing that in Eastern Indonesian societies topogenies are as common as genealogies and that certain Austronesian societies give preference to topogeny over genealogy (Fox 2006: 89). In Lamaholot, it seems that the place names are combined with the genealogies of spirits and ancestors.

\section{PAIRING THE WORDS (KODA TANAWIT)}

All ethnographies of Eastern Indonesia confirm the importance of lexical parallelism in ritual speech. Lexical, semantic and syntactic parallelism are all found in a recurrent and complex manner throughout Eastern Indonesia, a trait which James Fox has repeatedly highlighted, especially in two major works (Fox 1988, 2014).

Lamaholot ritual speech is called the 'language of paired lines' It is referred to by various expressions: kenahan' kenapén, koda tanawit, 'completed words', uwen matan, 'basis top', ina ana', 'mother child'. It encompasses different forms of oral performative genres, among them declaimed prayers (tutu marin/bokan maran), address speech (galan kénalan), narrative (opak) and, finally, songs (lian).

The complementarity is performed on many poetic levels, from the smallest to the largest: the syntagmatic level (one syntagm is completed by two words), the distich level (one line is completed by another line), the couplet level (one distich is completed by another distich), the song level (one strophe is completed by another strophe). All these levels have to be mastered by the singers. The most difficult task falls on the shoulders of the storyteller because he needs to master all the levels and to remember hundreds of syntagms perfectly.

Here, I shall consider only the syntagmatic level. Complementarity is distinguished by the use of several types of semantic compound which must be told together for them to make any sense. In the example below, several frozen sets are split:

$\begin{array}{ll}\begin{array}{l}\text { Wuno pito géré gitan } \\ \text { pari lema lodo réré }\end{array} & \begin{array}{l}\text { Seven Pleiades arise } \\ \text { five Antares set }\end{array} \\ \begin{array}{l}\text { Guté nala lakin tada } \\ \text { pilé nala ulen roja }\end{array} & \begin{array}{l}\text { Take a male goat } \\ \text { choose a male pig }\end{array} \\ \begin{array}{l}\text { Agon pai nala biné } \\ \text { tenan pai nala ana' }\end{array} & \text { Gather our sister } \\ \end{array}$


Belo pi naman tukan

Tuno' tutu Nogolewun

Bélo lakan Ema' jale
Cut in the middle of the dancing place

\author{
Burn and pray Nogo \\ cut Ema's womb
}

Excerpt from Haman opak bélun gurun gawak béola tugu, lines 1272 and the following (collected in Ratulodong, dokan gurun ritual, 8 November 2006).

The pairing is built on different kinds of combinations: contrary motion (lodo/géré) as the movement of the stars (Wuno Pari) mentioned in the first dyad is opposed; the first indicate the rainy season, the other the dry season; parallelism (gute/pilé-lakin/ulén) by using synonyms - which creates repetition and complementarity (Biné ana', Tono Wujo, burn/cut) as Bine' ana' and Nogo Ema, the name of the rice maiden, are frozen syntagms, but when they are sung, they are split into two lines).

Ritual poetry consists of a large number of these pairs which produce a whole by the association of two entities. Lamaholot speakers call this language koda tanawit. Although there are many examples, I shall mention only a few: sason rurén ('zither/ flute') for double flute and spirit, lewo tana ('village/ land') for ceremonial domain; ema' bapa' ('mother/ father') for parents, todo bawa ('beat/ drum') for a singing storyteller. They invade the entire poem to form oppositions and dyadic semantic units.

Lamaholot speakers are highly appreciative of the way the two lines are combined to produce a meaning.

The principle is that this [combination] of words belongs to our culture, our custom; this language makes it more pleasant to listen to. If we speak normally, we cannot experience the ritual speech (Ind. bahasa adat). Ritual speech needs this kind of language; it is necessary; we feel that it is good that they speak in ritual speech. For the songs, it is the same, they are all different, but again, the words link one to the other (bertanawit). (Bapa' Krowé Koten, p.c., Waiklibang, 2012).

Tanawit means to be achieved, complete (Ind. genap). Very few persons (only one or two in a village) are able to use this language fluently. The mark of ritual speech is the use of this language.

If parallelism is the characteristic of a large number of languages, it is the use of a particular parallelism and complementarity which seems unique to Lamaholot ritual speech. It goes beyond the merely stylistic: it implies the existence of a mental lexicon of different types of pairs which often share grammatical and phonological properties acquired by the speakers over time. The mental challenge is to recompose the pairs while listening to it. A narrative of 2,000 lines is full of hundreds of pairs of words which are frozen. 


\section{CONCLUSION}

By presenting a case study from an Eastern Indonesian society, I have tried to give some insights into why societies need to sing narratives. The three kinds of narrative still performed in the Tanjung Bunga Peninsula of Flores show that food, house and defence are the principal reasons for singing stories. Dumézil (1995: 76) has postulated that every human group must satisfy three requirements for survival - food, defence and the administration of the sacred (or today its ideological substitutes). In Tanjung Bunga, each of these needs is accomplished through rituals, the administration of the sacred taking precedence at all meetings. On these occasions, narrative, music and dance are invariably combined. The narratives are still performed right up to the present, first and foremost because there are still master poets who have the skill to sing them, and also because people still consider the rice to be a person who has to be welcomed and accompanied. The history of groups shaped by their migration route is still performed to ensure a group's precedence on the land. Last but not least, victory is still believed to be achieved by the accompaniment of words, songs and dance. Everything still needs to be done to document this ritual language and this ritual storytelling, by recording, publishing, translations and interpretations.

\section{REFERENCES}

Acri, Andrea. 2014. "Birds, bards, buffoons, and Brahmans; (Re)tracing the Indic roots of some ancient and modern performing characters from Java and Bali“", Archipel 88: 13-70.

Arndt, Paul. 1938. "Demon und Padzi, die Feindlichen Brüder des SolorArchipels ", Anthropos XXXIII: 1-58.

Arndt, Paul. 1940. Soziale Verhältnisse auf Ost-Flores, Adonara und Solor. Münster: Aschendorffsche Verlagsbuchhandlung.

Arndt, Paul. 1951. Religion auf Ostflores, Adonara and Solor. Wien-Mödling: St. Gabriel.

Arndt, Paul. 2002. Demon dan Paji; Dua bersaudara yang bermusuhan di kepulauan Solor. Maumere: Puslit Candraditya. [Seri Etnologi Candraditya no. 1.]

Barnes, Robert. 1982. "The Majapahit dependency Galiyao", Bijdragen tot de Taal-, Land- en Volkenkunde 138: 407-412.

Barnes, Robert. 1993. "Lamaholot", in: P. Hockings (ed.), Encyclopedia of World Cultures 5, pp. 154-157. Boston: G.K. Hall and Co.

Barnes, Robert. 2005. "A ritual resurgence in Eastern Indonesia", Anthropos 100: 359-377.

Barnes, Robert. 2011. "New village temple in Witihama, Adonara, Indonesia", Anthropos 106(2): 379-396.

Barnes, Ruth. 1987. "Weaving and non-weaving among the Lamaholot", Indonesia Circle 42: 17-31.

Benamou, Marc. 2010. Rasa; Affect and intuition in Javanese musical aesthetics. New York: Oxford University Press.

Dumézil, Georges. 1995. Mythe et épopée. Paris: Gallimard. 
Fox, James J. (ed.). 1988. To speak in pairs: Essays on the ritual languages of eastern Indonesia. Cambridge: Cambridge University Press.

Fox, James J. 2006. “Genealogy and topogeny; Toward an ethnography of Rotinese ritual place names", in: J. Fox (ed.), The poetic power of place; Comparative perspectives on Austronesian ideas of locality, pp. 89-100. Canberra: Pacific Linguistics, Research School of Pacific and Asian Studies, Australian National University.

Fox, James J. 2014. Explorations in semantic parallelism. Canberra: ANU Press. Friedberg, Claudine. 2011. "O imaginário e as praticas nas relações com os outros seres; Algumas pistas de reflexão com base em dados timorenses", in: Kelly Silva and Lucio Sousa (eds), Ita maun alin ... O livro do irmão mais novo; Afinidades Anthropologicas em torno de Timor-Leste, pp. 46-61. Lisbon: Edições Colibri.

Graham, Penelope. 1991. To follow the blood; The path of life in a domain of eastern Flores, Indonesia. PhD Thesis, Australian National University.

Kohl, Karl-Heinz. 2009. Raran Tonu Wujo; Aspek-aspek inti sebuah budaya lokal di Flores Timur. Maumere: Penerbit Ledalero.

Keraf, Gregorius. 1978. Morfologi dialek Lamalera. Ende: Arnoldus.

Kunst, Jaap. 1942. Music in Flores; A study of the vocal and instrumental music among the tribes living in Flores. Leiden: E. J. Brill. [Internationales Archiv Für Ethnographie, 42, Supplement.]

Lewis, Douglas. 1988. People of the source; The social and ceremonial order of Tana Wai Brama on Flores. Dordrecht-Holland: Foris.

Liwun, P. P. 1986. Usaha mempertemukan upacara lodong ana' dengan inisiasi Kristen. Maumere: Sekolah Tinggi Filsafat Katolik Ledalero.

Messner, Gerald Florian. 1989. "Jaap Kunst revisited. Multipart-singing in three east florinese villages fifty years later, a preliminary investigation", The World of Music 31(2): 3-48.

Nong, P. Petrus. 2009. Nitun wai matan: Mitologi Lamaholot tentang saudari air. Maumere: Penerbit Ledalero.

Pampus, Karl-Heinz. 2001. Mué moten koda kiwan: Kamus bahasa Lamaholot; Dialek Lewolema, Flores Timur. Frankfurt am Main: Frobenius-Institut.

Rappoport, Dana. 2010a. “L'énigme des duos alternés à Flores et Solor (Lamaholot, Indonésie)“" Archipel 79:215-256.

Rappoport, Dana. 2010b. “Audio Disc: Indonesia: Songs from the islands of Flores and Solor/ Indonésie: chants des îles de Flores et Solor", in: Archives internationales de musique populaire (AIMP) XCV. Lausanne: VDE-Gallo.

Rappoport, Dana. 2011. "To sing the rice in Tanjung Bunga (eastern Flores, Indonesia)", in: B. Abels (ed.), Austronesian soundscapes; Performing arts in Oceania and Southeast Asia, pp. 103-131. Amsterdam: Amsterdam University Press.

Rappoport, Dana. 2013. "Sound archives; Indonesia: eastern Flores, Solor, Adonara, Lembata, sound recordings 2006-2007". [Http:/ / archives.cremcnrs.fr/archives/collections/CNRSMH_I_2007_006/] 
Rappoport, Dana. 2014. "Songs and sorrow in Tanjung Bunga; Music and the myth of the origin of rice (Lamaholot, Flores, Indonesia)", Bijdragen tot de Taal-, Land-en Volkenkunde 170 (2-3): 215-249.

Rappoport, Dana. 2015. "Musique et rituel dans l'Est insulindien (Indonésie orientale et Timor-Leste): premier jalons", Archipel 90 (2015): 275-306.

Rappoport, Dana. Forthcoming. "Singing in dangerous places (Flores, Lamaholot, Indonesia) “.

Steenbrink, Karel. 2003. Catholics in Indonesia 1808-1942; A documented history; Volume 1: A modest recovery 1808-1903. Leiden: KITLV Press.

Taum, Yapi Yoseph. 1996. Kisah Wato Wele-Lia nurat dalam tradisi puisi lisan Flores Timur. Jakarta: Yayasan Obor Indonesia and Yayasan Asosiasi Tradisi Lisan.

Waterson, Roxana. 1993. The Living House; An anthropology of architecture in South-East Asia. Singapore: Oxford University Press.

Yampolsky, Philip. 1995. "Vocal and instrumental music from East and Central Flores (Music of Indonesia, 8)". [Smithsonian Folkways Recordings.] 